\title{
Evidence of saxitoxin derivates as causative agents in the 1997 mass mortality of monk seals in the
} Cape Blanc Peninsula

Maribel Reyero, ${ }^{1,2}$ Emiliano Cacho, Ana Martínez, Jesús Vázquez, Anabel Marina, ${ }^{3}$

Santiago Fraga and José M. Franco ${ }^{5}+\dagger$

1

Instituto Español de Oceanografía, Apt. 1552, 36200 Vigo, Spain

3 European Community Reference Laboratory on Marine Biotoxins, Estación Marítima s/n, 36271 Vigo, Spain

${ }^{4}$ Centro de Biología Molecular 'Severo Ochoa' (CSIC-UAM) Universidad Autónoma de Madrid, 28049 Madrid, Spain

${ }^{5}$ Instituto de Investigaciones Marinas (CSIC), c/Eduardo Cabello 6, 36208 Vigo, Spain

*Correspondence to: Dr José M. Franco, Instituto Español de Oceanografía, Apt 1552, 36200 Vigo, Spain

†Instituto Español de Oceanografía, Apt 1552, 36200 Vigo, Spain

Sponsors: Comisión Interministerial de Ciencia y Tecnología; number ALI95-1012-C05-01

Abstract Monk seals in Cape Blanc (Western Sahara coast) suffered a mass mortality Turing May-July 1997 which was attributed to a morbilivirus. High performance liquid chromatography (HPLC) analysis on tissues of seals killed during the outbreak and on related fauna showed peaks with retention times coincident with those of some saxitoxin derivatives but their identity of these toxins by mass spectrometry (MS), supporting the hypothesis that this mortality of monk seals was caused by biotoxins rather than by a morbillivirus.

Key words: monk seals; mass mortality; PSP toxins; HPLC; MS

\section{Introduction}

In May-July 1997, a mass mortality of the colony of Mediterranean monk seals (Monachus monachus) established in NW Africa was observed for about two-thirds of the population. A preliminary survey (Osterhaus et al., 1997) was unable to detect the presence of paralytic shellfish toxins in tissues of seal 
carcasses, but using standard mouse bioassays of American Official Analytical Chemist (AOAC) a morbillivirus was found in the organs of three seals. This served as a basis to claim that the morbillivirus was the causative agent of the mortality. However, neither the clinical signs of affected individuals, the macroscopic observation of corpses, the results of the anatomopathological examination of tissues of dead individuals nor the epidemiology of the mortality were consistent with the action of a morbillivirus. It has been generally agreed that if a morbillivirus was responsible for most of the mortality, the effect was very different from that observed in other morbillivirus outbreaks that have affected marine mammals in the past (Harwood, 1998). Instead, the above elements were all consistent with an intoxication of the paralytic shellfish poisoning (PSP) type. High Performance Liquid Chromatography (HPLC) analysis on tissues of seals killed during the outbreak and on related fauna showed peaks with retention times coincident with those of some saxitoxin derivatives (Franco and Fernández, 1993). We present here results of further analyses that prove the presence of saxitoxin derivatives in these samples, supporting the hypothesis that the mortality of monk seals was caused by biotoxins rather than by a morbillivirus (Harwood, 1998; Hernández et al., 1998).

\section{Material and methods}

We analysed tissue samples from 8 affected seals: liver from 7 seals, muscle from 6 seals, nervous tissue from 5seals, kidney from 1 seal, spleen from 1 seal and juices from the stomach contents of 1 seal, as well as the viscera from 12 fishes and 1 cuttlefish, muscle from 2 fishes, 2 whole mussels, 4 barnacles and 1 oyster. All these samples were collected between 17 May and 10 June 1997, which corresponded to the period when most dead seals were found. Samples were extracted following the protocol for mouse bioassay of the AOAC (1990), but the heating stage was omitted to prevent potential alteration of the labile compounds. Extracts were analysed by reverse phase-HPLC with postcolumn oxidation and fluorometric detection (Franco and Fernández, 1993) to determine the possible presence of saxitoxinrelated toxins.

In order to observe the death symptoms of mice, rather than to quantify the toxins, when the AOAC standard bioassays were below the detection limit, other assays were run but injecting $2 \mathrm{ml}$ of extract instead $1 \mathrm{ml}$ as in the standard AOAC mouse bioaasay. In those cases, blanks were also done. The result of the sample of liver seal (346 Afp) is based on the standard bioassay.

To analyse the presence of toxins by mass spectrometry, 300-500 $\mu$ l of each sample extract were typically cleaned in two fractions by injection into a LiChrospher 100 RP8, $5 \mu \mathrm{m}(250$ x $4.6 \mathrm{~mm})$ column and isocratic elution with 10\% CH3CN: 90\% $10 \mathrm{mM}$ heptafluorbutyric acid (HFBA) at $1 \mathrm{ml}$ 
$\min ^{-1}$. No toxins were detected in the first fraction; the second fraction containing 1-Nhydroxy-saxitoxin (neoSTX) and decarbamoyl-saxitoxin (dcSTX) was collected, and about one-third was dried down and resuspended in methanol / water (1:1) containing $0.1 \%$ formic acid to concentrate the sample about 20 fold before mass analysis. Some fractions were further diluted in the same medium in order to improve nanospray ionization. An ion-trap mass spectrometer model LCQ (Finnigan, ThermoQuest, USA) was used in this work. Off-line nanospray ionization was carried out using disposable gold-coated capillary probes (The Protein Analysis Company, Denmark), as described previously (Locke and Thibault, 1994; Marina et al., 1998). Aliquots (1 $\mu \mathrm{L})$ of the previously cleaned and concentrated samples were placed on the tip of the nanospray probe and subjected to analysis.

The specific detection of toxins at high sensitivities was performed by looking for the appearance of daughter ions (239 and $298 \mathrm{Da}$ ) produced by the fragmentation of the corresponding precursor ions (257 and $316 \mathrm{Da}$, for dcSTX and neoSTX, respectively), and taking advantage of the ability of the ion trap to concentrate analyte ions and the extended analysis time allowed by the nanospray method. Isolation width of parent ions was set to only $1 \mathrm{Da}$, and collision energies were manually increased until the specific fragments were stably detected above background after averaging a minimum of 500 scans using an injection time of $500 \mathrm{~ms}$. These conditions allowed the highly specific detection of each of the toxins with a practical detection limit of about $0.4 \mu \mathrm{M}$. Sample clean-up and concentration allowed the detection of toxins present in crude extracts at levels below $100 \mathrm{nM}$.

\section{Results and discussion}

In the HPLC analysis of all samples a peak appeared at the retention time of the dcSTX standard (Table 1). An additional peak at the retention time of the neoSTX standard, supplied by the project EUR 18318 of European Commission, was also detected in some of the samples (examples of the HPLC analyses are given in Figure 1). The mouse bioassays produced symptoms of PSP intoxication in 9 samples: 7 from seals and 2 from fish viscera. In order to confirm the chemical identity of the HPLC peaks and support our bioassay results, several samples were further analysed by tandem mass spectrometry (Figure 2). The fragmentation patterns specific for dcSTX were detected in 8 out of 9 seal samples and in the 4 samples of fishes and mussels. NeoSTX was detected in 6 seal samples and in 2 fish samples (Table 1).

The origin of the detected toxins is difficult to establish. Toxin profiles can be used as a fingerprint to trace the transmission of PSP toxins through the trophic web but with caution, as metabolism of the affected species may cause changes in those profiles (Shimizu and Yoshioka, 1981). Based on the toxin 
composition of the analysed samples, the dinoflagellate Gymnodinium catenatum appears to be the most likely origin of the toxins. Cultures of G. catenatum usually yield a wide toxin profile, typically containing neoSTX and dcSTX, as well as four sulphocarbamoyl-sulphate-saxitoxins (C1 to 4), two sulphocarbamoyl-saxitoxins (GTX5, GTX6) and traces of GTX2 and GTX3 (Oshima et al., 1993; Donker et al., 1997; Bravo et al., 1998). Although Alexandrium minutum has been reported from Cape Blanc area (Herna'ndez et al., 1998) its presence in the area is doubtful, and this species lacks the two toxins detected in the seals samples (Hallegraeff et al., 1991; Franco et al., 1995; Forteza et al., 1998). Another possibility is Pyrodinium bahamense; resting cysts of this species have been reported for the first time in the Eastern Atlantic in sediments of the Portuguese shelf (Amorim and Dale, 1998). Although $P$. bahamense var. bahamense, which is common in the Caribbean Sea is nontoxic, $P$. bahamense var. compressa which is common in other tropical areas has a toxin profile (Oshima, 1989) very similar to that observed in the Cape Blanc samples. The known distribution range of G. catenatum in the Northeast Atlantic Ocean extends from the northwest of the Iberian Peninsula to the Moroccan coasts, its southern limits remaining imprecise due to insufficient information. This dinoflagellate has been associated to human intoxications by mollusc consumption as far south as Essaouira (Tahri-Joutei, 1998). Given that G. catenatum is a warm-water species, it is feasible that its actual distribution range extends further south to reach Cape Blanc. G. catenatum is particularly well adapted to producing blooms in upwelling areas such as that occurring off northwest Africa (Hallegraeff and Fraga, 1998).

P. bahamense is a tropical species that in some regions, like Mexico of southeast Asia, overlaps in distribution to G. catenatum; if resting cysts have been observed off the Portuguese coast, its presence in more southern and warmer waters is likely, but this has to be proved and toxicity tested. However, since certain cyanobacteria and eubacteria are also known to produce PSP toxins (Negri et al., 1997; Kodama, 1990), their potential involvement cannot be totally dismissed at present.

PSP toxins affect higher vertebrates when transmitted through the trophic web. Taking into account that the adult seal body mass is about $400 \mathrm{~kg}$, its fish consumption is about $20 \mathrm{~kg}$ per day, about $20 \%$ of the fish body mass is the viscera and, as shown above, the dcSTX concentration in the fish viscera averages $0.6 \mu \mathrm{gg}^{-1}$, it canbe deduced that an adult seal would ingest $6 \mu \mathrm{g}$ dcSTX per kg body mass per day. Given that in humans the minimum lethal dose via food is 7-16 $\mu \mathrm{g}$ of STX per kg (Schantz et al., 1975), it is therefore probable that food poisoning caused by STX derivatives was the actual cause of the mass mortality. Moreover, the dependence of seals on marine life would make them particularly vulnerable to neurotoxic substances affecting respiratory function. Information available on PSP intoxication in marine mammals is extremely limited (Geraci et al., 1989). However, it is likely that a number of unexplained mortality events occurring in the past have indeed been caused by ingestion of toxins 
produced by microorganisms (microalgae, eubacteria, cyanobacteria).

\section{Acknowledgements}

We thank Alex Aguilar, Mauro Hernández and Luis M. González for their helpful discussion, and for providing samples. This work was supported by Project ALI 951012-CO5-01 of the Comisión Interministerial de Ciencia y Tecnología.

\section{References}

Amorim A, Dale B. 1998. Distribution of cysts from toxic or potentially toxic dinoflagellates along the Portuguese coast. In Harmful Algae, Reguera, B, Blanco, J, Fernández, ML, Wyatt, T (eds). Xunta de Galicia and IOC of UNESCO: Vigo; 64-65.

AOAC. 1990. PSP Biological Method. Final action. In Official Methods of Analysis (15th edn), Hellrich K (ed). Ass Off Anal Chem: Arlington, Virginia, USA; 881-882.

Bravo I, Franco JM, Reyero MI. 1998. PSP toxins composition of Gymnodinium catenatum resting cyst. In Harmful Algae, Reguera B, Blanco J, Fernández ML, Wyatt, T (eds). Xunta de Galicia and IOC of UNESCO: Vigo; 356-360.

Donker S, Reyero MI, Reguera B, Franco JM. 1997. Perfil de toxinas PSP de seis cepas de Gymnodinium catenatum de Galicia. In V Reunión Ibérica sobre Fitoplacton Tóxico y Biotoxinas, Vyeites JM, Leira F (eds). ANFACO-CECOPESCA: Vigo; 69-76.

Franco JM, Fernández P. 1993. Separation of PSP toxins by RP-HPLC, with postcolumn reaction and fluorometric detection. Chromatographia 35:613-620.

Franco JM, Fraga S, Zapata M, Bravo I, Fernández P, Ramilo I. 1995. Comparison between different strains of genus Alexandrium of the minutum group. In Harmful Marine Algal Blooms, Lassus P, Arzul G, Erard E, Gentien P, Marcaillou, C (eds). Tech et Docum Lavoisier, Intercep Ltd: Paris; 53-58.

Forteza V, Quetglás G, Delgado M, Reyero MI, Fraga S, Franco JM, Cacho E. 1998. Development of a toxic bloom of Alexandrium minutum Halim (Dinophyceae) in Palma de Mallorca harbour (Balearic Islands, Western Mediterranean). In Harmful Algae, Reguera B, Blanco J, Fernández ML, Wyatt, T (eds). Xunta de Galicia and IOC of UNESCO: Vigo; 58-60.

Geraci JR, Anderson DM, Timperi R, Aubin DJ, Early GA, Prescott JH, Mayo CA. 1989. Humpback whales (Megaptera novaeangliae) fatally poisoned by dinoflagellate toxin. J Fish Aquatic Sci 46:1895- 1898.

Hallegraeff GM, Bolch C, Blackburn S, Oshima Y. 1991. Species of the toxigenic dinoflagellate genus Alexandrium in Southeastern Australian waters. Botanica Marina 34:575-587. 
Hallegraeff GM, Fraga S. 1998. Bloom dynamics of the toxic dinoflagellate Gymnodinium catenatum, with emphasis on Tasmanian and Spanish coastal waters. In Physiological Ecology of Harmful Algal Blooms, Anderson DM, Cembella AD, Hallegraeff GM (eds). Springer-Verlag: Berlin, Heidelberg; 59-80.

Harwood J. 1998. What killed the monk seals? Nature 393:17-18.

Hernández M, Robinson I, Aguilar A, Gonza'lez LM, López-Jurado LF, Reyero MI, Cacho E, Franco JM, López-Rodas MV, Costas E. 1998. Did algal toxins cause monk seal mortality? Nature 393:2829.

Kodama M. 1990. Possible links between bacteria and toxin production in algal blooms. In Toxic Marine Phytoplankton, Granéli E, Sundström B, Edler L, Anderson DM (eds). Elsevier: New York; 52-61.

Locke SJ, Thibault P. 1994. Improvement in detection limits for the determination of paralytic shellfish poisoning toxins in shellfish tissues using capillary electrophoresis/electrospray mass spectrometry and discontinous buffer systems. Anal Chem 66:3436-3446.

Marina A, García MA, Albar JP, Yaüe J, López de Castro JA, Vázquez J. 1999. High sensitivity analysis and sequencing of peptides and protein by cuadrupole ion trap mass spectrometry. $J$ Mass Spectrom 34:17-27.

Negri A, Jones J, Blackburn SJ, Oshima Y, Onodera II. 1997. Effect on culture and bloom development and of sample storage on PSP in the cyanobacterium Anabaena circinalis. J Phycol 33:26-35.

Oshima Y. 1989. Toxins in Pyrodinium bahamense var. compressum and infested marine organisms. In Biology, Epidemiology and Management of Pyrodinium Red Tides, Hallegraeff GM, MacLean JL (eds). ICLARM Proceedings: Manila; 73-79.

Oshima Y, Blackburn SI, Hallegraeff GM. 1993. Comparative study on paralytic shellfish toxin profiles of the dinoflagellate Gymnodinium catenatum from three different countries. Mar Biol 116:471-476.

Osterhaus A, Groen J, Niesters H, van de Bildt M, Martina B, Vedder L, Vos J, van Egmond H, Ba AS, Barham MEO. 1997. Morbillivirus in monk seal mass mortality. Nature 388:838-839.

Schantz EJ, Ghazarossian VE, Schnoes HK, Strong FM, Springer JP, Pezzanite JO, Clardy J. 1975. Paralytic poisons from marine dinoflagellates. In Toxic Dinoflagellate Blooms, Lo Cicero VR (ed). Massachusetts Science and Technology Foundation: Wakefield; 267-274.

Shimizu Y, Yoshioka M. 1981. Transformation of PSP toxins as demonstrated in scallop homogenates. Science 212:547-549.

Tahri-Joutei L. 1998. Gymnodinium catenatum Granam blooms on Moroccan shores. In Harmful Algae, Reguera, B, Blanco, J, Fernández, ML Wyatt, T (eds). Xunta de Galicia and IOC of UNESCO: Vigo 66-67. 
Table 1. PSP toxins in several organs of monk seal and other samples

\begin{tabular}{|c|c|c|c|c|c|c|c|}
\hline $\begin{array}{l}\text { Seals/other } \\
\text { samples }\end{array}$ & Date & Sample & $\begin{array}{l}\text { Mousea } \\
\text { bioassay }\end{array}$ & \multicolumn{2}{|c|}{$\begin{array}{l}\text { HPLC in } \mu g \\
100 g^{-1} \text { w.w. }\end{array}$} & \multicolumn{2}{|c|}{ Detection by $\mathrm{MS}^{\mathbf{b}}$} \\
\hline 335AM & $21 / 5 / 97$ & liver & $11-15$ min & 18.4 & $\operatorname{tr}$ & + & + \\
\hline 336AM & $25 / 5 / 97$ & liver & 11-15 min & 0.8 & $\operatorname{tr}$ & + & + \\
\hline 342SF & $3 / 6 / 97$ & kidney & $>25 \min$ & 0.6 & $\operatorname{tr}$ & + & nd \\
\hline 345SM & 3/6/97 & liver & $11-15 \mathrm{~min}$ & 28.0 & 8.4 nd & + & + \\
\hline & & $\begin{array}{l}\text { Sk. } \\
\text { muscle }\end{array}$ & $>25$ min & 12.0 & & + & + \\
\hline 346Afp & 3/6/97 & liver & $\begin{array}{c}47 \mu g S T X e q \\
100 \mathrm{~g}^{-1}\end{array}$ & 19.2 & 10.8 nd & + & + \\
\hline & & brain & $>25 \mathrm{~min}$ & 4.0 & & + & nd \\
\hline 347AM & 3/6/97 & liver & $>25 \min$ & 10.6 & 8.0 nd & + & nd \\
\hline & & brain & $>25 \min$ & 3.6 & & nd & nd \\
\hline $\begin{array}{l}\text { Unidentified } \\
\text { fish }\end{array}$ & 29/5/97 & whole & $>25 \min$ & 8.4 & $\operatorname{tr}$ & + & + \\
\hline Mussels & $3 / 6 / 97$ & meat & $>25 \min$ & 12.6 & $\operatorname{tr}$ & + & nd \\
\hline Fish D. s. & 3/6/97 & viscera & 20-25 min & 27.6 & $\operatorname{tr}$ & + & nd \\
\hline Fish D. $p$. & 3/6/97 & viscera & 20-25 min & 90.0 & $\operatorname{tr}$ & + & + \\
\hline
\end{tabular}

Seals: AM: adult male, SM: subadult male, SF: subadult female, Afp: pregnant adult female. Mussels: Mytilus galloprovincialis. Fish: D. s.: Diplodus sargus, D. p.: Dicentrarchus punctatus.

${ }^{\mathrm{a}}$ The first number is the time (min) when PSP toxicity symptoms appear and the second number is the death time (min) by injection of $2 \mathrm{ml}$ of extract. Only the liver sample of the 346Afp seal could be quantified with $1 \mathrm{ml}$ extract.

b nd: not detected tr: traces, +: positive presence. 


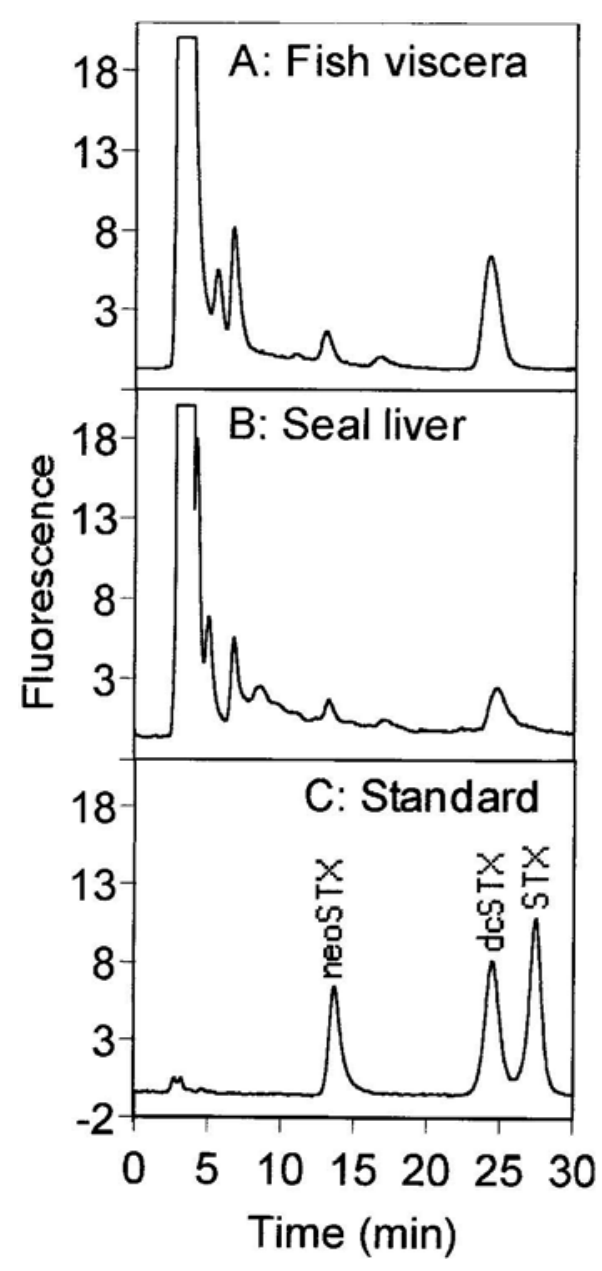

Figure 1. Chromatograms of viscera of (A) Dicentrarchus punctatus, (B) liver of monk seal and (C) standard toxins
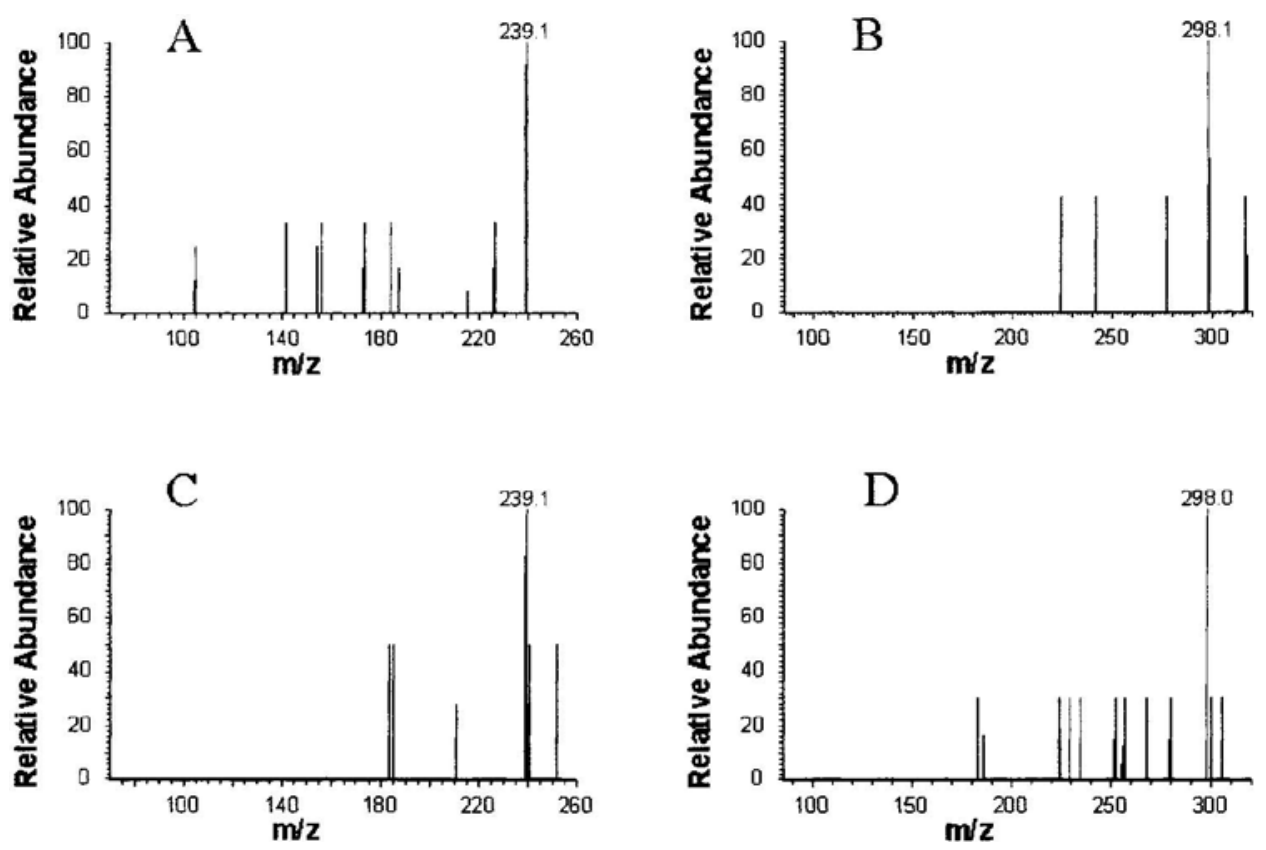
Figure 2. Specific detection of dcSTX (A and C panels) and neoSTX (B and D panels) in viscera of Dicentrarchus punctatus and monk seal liver extracts (upper and lower panels, respectively) by nanospray ion-trap mass spectrometry. Molecular ions of either dcSTX (257 Da) or neoSTX (316 Da) were isolated inside the trap and subjected to fragmentation. The specific fragments at the masses indicated are characteristic of the presence of each of the toxins 